\title{
Chronic Subdural Hematoma Associated with Acute Biphenotypic Leukemia: A Case Report
}

\author{
Akut Bifenotipik Lösemi İlişkili Kronik Subdural Hematom: Olgu Sunumu
}

\author{
Besime Utku1, Uygar Utku² \\ ${ }^{1}$ Kocaeli Derince Training and Research Hospital, Clinic of Emergency Medicine, Kocaeli, Turkey \\ 2Kocaeli Derince Training and Research Hospital, Clinic of Neurology, Kocaeli, Turkey
}

\section{Summary}

Spontaneous chronic subdural hematoma associated with neoplasm is a rare disorder. A rare case of chronic subdural hematoma associated with acute biphenotypic leukemia is presented here. A 78-year-old woman who was diagnosed as acute biphenotypic leukemia by hematology division developed a large chronic subdural hematoma. She presented to our emergency medicine with left-sided weakness. Her non-contrast brain computerized tomography showed a non-traumatic, rightsided, large, chronic subdural hematoma. She was treated with urgent hematoma evacuation by neurosurgery and had no neurological deficits after that operation. The case highlights the importance of paying attention to acute biphenotypic leukemia patients for important complications such as subdural hematomas. (Turkish Journal of Neurology 2015; 21:77-8)

Key Words: Subdural hematoma, acute biphenotypic leukemia

\section{Özet}

Neoplazi ilişkili spontan kronik subdural hematom nadir görülen bir rahatsılılıtır. Burada akut bifenotipik lösemi ile ilişkili nadir görülen bir kronik subdural hematom olgusu sunulmuştur. Hematoloji bölümünden akut bifenotipik lösemi tanısı almış 78 yaşında kadın hastada geniş, kronik subdural hematom meydana gelmiştir. Hasta sol tarafında güçsüzlük ile yakınlarınca hastanemiz acil servisimize getirilmiştir. Çekilen kontrastsız beyin bilgisayarlı tomografisinde travmatik olmayan, să̆ yerleşimli, geniş, kronik subdural hematom gözlendi. Beyin cerrahi bölümünce değerlendirildikten sonra acil olarak hematomu boşaltılan hastanın operasyon sonrası nörolojik defisiti yoktu. Olgu, nadir görülen kronik subdural hematom gelişmiş akut bifenotipik lösemi hastalarında subdural hematom gibi önemli komplikasyonlara dikkat çekmektedir. (Türk Nöroloji Dergisi 2015; 21:77-8)

Anahtar Kelimeler: Subdural hematom, akut bifenotipik lösemi

\section{Introduction}

There are two main groups of subdural hematoma in patients with malignancies: subdural hematoma related to predisposing factors and spontaneous non-traumatic subdural hematoma. The first group is more frequently associated with solid tumors, while spontaneous hematoma is mainly associated with hematological malignancies (1). Large subdural hematoma is more frequently found in acute versus chronic leukemia $(2,3)$. We present a favorable clinical course of acute biphenotypic leukemia, simultaneously presenting with a large chronic subdural hematoma.

\section{Case Report}

A 78-year-old female patient presented with left-sided hemiparesis to the emergency service. She had an increasing fatigue for two weeks. Routine laboratory tests revealed anemia in the internal medicine outpatient clinic. The total blood count 
was: platelets $76000 / \mu \mathrm{L}$, hemoglobin $8.1 \mathrm{~g} / \mathrm{dL}$, red blood cells $3100000 / \mu \mathrm{L}$, and white blood cells $4200 / \mu \mathrm{L}$. The bone marrow biopsy showed a cellular population consisting entirely of blastocytes. A diagnosis of acute biphenotypic leukemia (AML/ ALL B lymphoblastic type) was made but she did not have induction therapy because of her advanced age. She was using a calcium channel blocker for her hypertension for five years. She had no trauma history. Her systolic blood pressure was normal. On neurological examination, she became intermittently confused and had difficulty following complex commands. There were hemiparesis such as $2 / 5$ and Babinski's sign on the left side. Brain computerized tomography (CT) revealed a large fronto-temporoparietal chronic subdural collection, with mass effect on the right side (Figure 1). Platelets were $15000 / \mu \mathrm{L}$ in control. Platelet transfusion was administered and then hematoma was evacuated by burr hole.

\section{Discussion}

Large subdural hematoma may occur secondary to multiple factors, such as dural blood vessel occlusion by tumor cells that may rupture within the subdural compartment; tumor necrosis and chemotherapy induced thrombocytopenia or disseminated intravascular coagulation secondary to underlying malignancy (4).

Acute biphenotypic leukemia or acute leukemia with a single population of blasts co-expressing markers of two different lineages, is a rare clinical entity (5). Due to thrombocytopenia and massive blood clotting activation with coagulation factors consumption, the risk of bleeding reaches is substantial in these patients. Acute biphenotypic leukemia can lead to the critical conditions such as chronic subdural hematoma with coagulopathy $(5,6)$. We

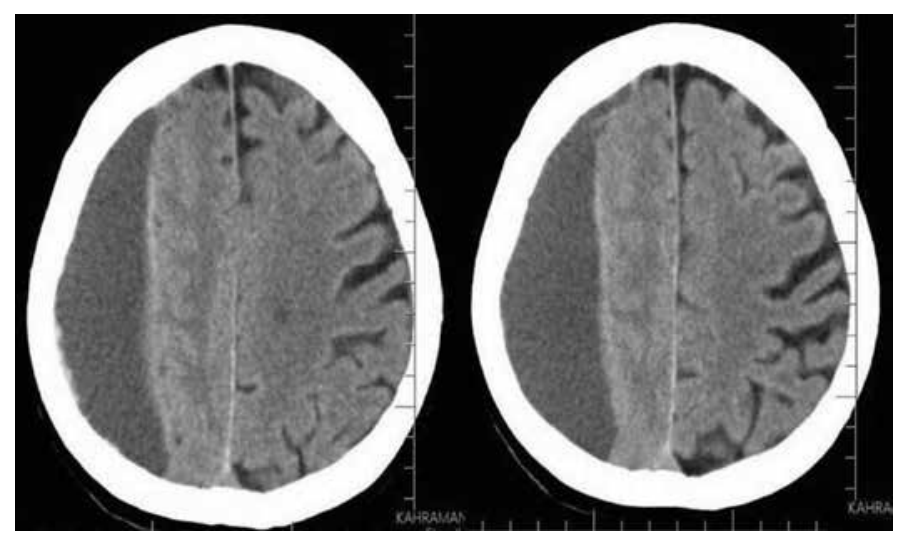

Figure 1. Non-contrast computerized tomography scan of the brain shows a large subdural hemoatoma on the right side with mass effect presented an acute biphenotypic leukemia patient, simultaneously presenting with a large chronic subdural hematoma.

Consumption of platelets and coagulation factors causes bleeding symptoms, which may lead to hemorrhage. The critical care of a patient with biphenotypic acute leukemia before and after the surgery is crucial. The most important supportive tool, therefore, is the judicious use of platelet transfusion. Platelet transfusions represent an essential part of the modern supportive care for all patients with acute leukemia, including acute biphenotypic leukemia patients. Prophylactic transfusion of platelets has resulted in a significant decrease in the incidence of fatal bleeding. Current recommendations for patients with acute biphenotypic leukemia suggest that platelets should be transfused to maintain the platelet count above $20 \times 109 / \mathrm{L}$ in patients who are not actively bleeding and above $50 \times 109 / \mathrm{L}$ in those with active bleeding (6). Our patient had severe thrombocytopenia. Blood and platelet transfusion were administered and then hematoma was evacuated by right parietal burrhole.

In conclusion, the case highlights the importance of paying attention to acute biphenotypic leukemia patients for important complications such as subdural hematomas.

Concept: Besime Utku, Uygar Utku

Design: Besime Utku

Literature Search: Besime Utku

Writing: Besime Utku

Peer-review: Externally peer-reviewed.

Conflict of Interest: No conflict of interest was declared by the authors.

Financial Disclosure: The authors declared that this study has received no financial support.

\section{References}

1. Minette SE, Kimmel DW. Subdural hematoma in patients with systemic cancer. Mayo Clin Proc 1989;64:637-642.

2. Jourdan E, Dombret H, Glaisner S, Miclea JM, Castaigne S, Degos L. Unexpected high incidence of intracranial subdural haematoma during intensive chemotherapy for acute myeloid leukaemia with a monoblastic component. Br J Haematol 1995;89:527-530.

3. Bromberg JE, Vandertop WP, Jansen GH. Recurrent subdural haematoma as the primary and sole manifestation of chronic lymphocytic leukaemia. Br J Neurosurg 1998;12:373-376.

4. Comanescu A, Roşca E, Bota M, Ninulescu G. Chronic subdural hematoma in a patient with acute myeloid leukemia and dural metastatic infiltration. Rom J Morphol Embryol 2008;49:259-262.

5. Zhao XF, Gojo I, York T, Ning Y, Baer MR. Diagnosis of biphenotypic acute leukemia: a paradigmatic approach. Int J Clin Exp Pathol 2009;3:75-86.

6. Falanga A, Russo L, Tartari CJ. Pathogenesis and treatment of thrombohemorrhagic diathesis in acute promyelocytic leukemia. Mediterr J Hematol Infect Dis 2011;3:2011068. 